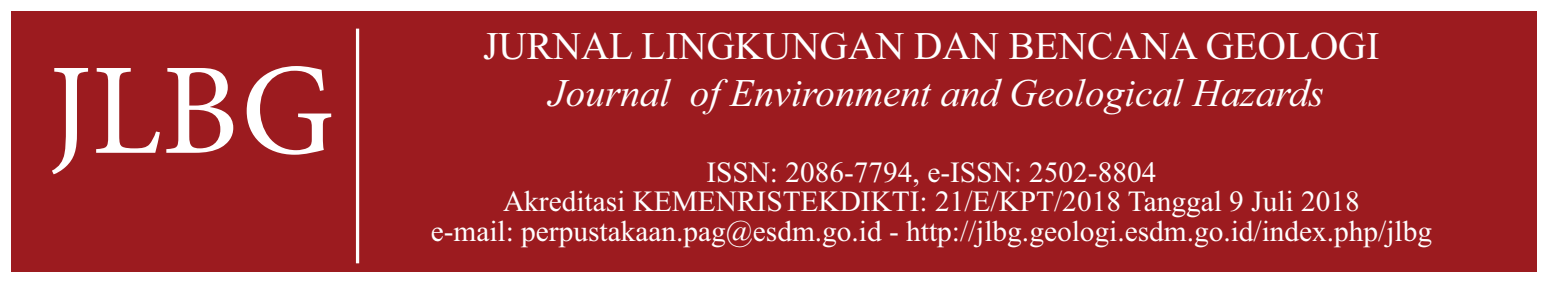

\title{
Pola Kejadian Tsunami dan Perkembangan Manajemen Bencana di Indonesia setelah Tsunami Samudra Hindia Tahun 2004: Sebuah Tinjauan
}

\section{Spatial Pattern of Tsunami Events and Disaster Management Development in Indonesia Following the 2004 Indian Ocean Tsunami: A Review}

\author{
Bachtiar W. Mutaqin, Ikhwan Amri, dan Bagas Aditya \\ Departemen Geografi Lingkungan, Fakultas Geografi, Universitas Gadjah Mada \\ Jln. Kaliurang, Bulaksumur, Yogyakarta, 55281, Indonesia \\ e-mail: mutaqin@ugm.ac.id
}

Naskah diterima 20 Desember 2019, selesai direvisi 29 Agustus 2020, dan disetujui 30 Agustus 2020

\begin{abstract}
ABSTRAK
Indonesia memiliki catatan sejarah yang panjang dengan bencana tsunami. Dari sejumlah kejadian tsunami yang ada, tsunami Samudra Hindia tahun 2004 dinilai sebagai bencana alam yang paling mematikan sepanjang abad dan paling berperan dalam mengubah paradigma manajemen kebencanaan di Indonesia. Penelitian ini bertujuan untuk meninjau pola kejadian tsunami dan perkembangan manajemen bencana di Indonesia setelah tsunami tahun 2004 dengan memanfaatkan database tsunami dan tinjauan literatur. Analisis deskriptif dilakukan terhadap distribusi spasial tsunami, faktor pemicu tsunami, dampak tsunami, maupun informasi detil kejadian tsunami berdasarkan data dari instansi terkait dan studi sebelumnya. Sebanyak 22 kejadian tsunami telah tercatat di Indonesia selama 2005-2018, di mana sebagian besar lokasi tsunami terkonsentrasi di Pulau Sumatra bagian baratdan bersumber dari Samudra Hindia. Tujuh kejadian diantaranya menimbulkan dampak signifikan, termasuk dua tsunami terakhir yang dipicu oleh faktor non-seismik. Sistem manajemen bencana sebenarnya telah mengalami perubahan secara besar-besaran setelah tsunami tahun 2004, mulai dari berlakunya peraturan perundang-undangan tentang penanggulangan bencana, pembentukan institusi baru untuk penanggulangan bencana, hingga konstuksi sistem peringatan dini tsunami (InaTEWS). Meskipun telah berfokus pada upaya preventif, dampak tsunami dalam beberapa tahun terakhir masih cukup besar. Hal ini dipengaruhi oleh 4 faktor utama: (1) konsentrasi penduduk yang tinggi di area bahaya tsunami, (2) terbatasnya infrastruktur diseminasi peringatan dini, (3) kurangnya kesadaran masyarakat untuk melakukan evakuasi mandiri tanpa menunggu peringatan, dan (4) sistem peringatan dini tsunami belum mempertimbangkan faktor non seismik.
\end{abstract}

Kata kunci: manajemen bencana, peringatan dini, pola spasial, tsunami, Indonesia

\section{ABSTRACT}

Indonesia has a long history with the tsunami. From numerous tsunami events in the world, the 2004 Indian Ocean tsunami was considered as the deadliest natural disaster of the century and had the most role in changing the paradigm of disaster management in Indonesia. This study aims to review the spatial pattern of tsunami events and the development of disaster management in Indonesia following the 2004 tsunami through the tsunami database and literature review. We carried out a descriptive analysis of the spatial distribution of the tsunami, tsunami trigger factors, tsunami impacts, and other detailed information on tsunami events based on data from relevant agencies and previous studies. At least there are 22 tsunami events were recorded in Indonesia in the period of 2005-2018, where most of its locations were concentrated on the western part of Sumatra Island and sourced from the Indian Ocean. We had identified that seven of these events have significant impacts, including the last two tsunamis triggered by non-seismic factors. The disaster management system has actually improved drastically following the 2004 tsunami, such as the enactment of laws and regulations on disaster management, the establishment of special institutions for disaster management, and the construction of a tsunami early warning system (InaTEWS). Although it has focused on preventive measures, tsunami impacts in recent years are still quite large. This situation is affected by four factors: 
(1) high and dense population in the tsunami hazard area, (2) limited infrastructure for early warning dissemination, (3) lack of public awareness to conduct evacuations following the disaster events, and (4) early warning systems for tsunami has not considered yet the non-seismic factors.

Keywords: disaster management, early warning, spatial pattern, tsunami, Indonesia

\section{PENDAHULUAN}

Tsunami merupakan bencana alam yang memiliki dampak destruktif yang masif terhadap wilayah yang dilaluinya. Kejadian tsunami di dunia dalam catatan sejarah telah menimbulkan korban jiwa yang sangat besar, di antara kejadian tsunami tersebut adalah tsunami Samudra Hindia 2004, tsunami Chili 2010, dan tsunami Jepang 2011. Secara terminologi, tsunami diartikan sebagai sebagai suatu gelombang air laut yang ditimbulkan dari perubahan/pergerakan vertikal dari kolom air secara tiba-tiba (Bryant, 2014; Mutaqin drr., 2019a). Tsunami merupakan bencana yang memiliki frekuensi kejadian yang rendah dengan periode ulang yang panjang, namun memiliki magnitudo yang besar (Wong, 2009). Selain itu, bencana tsunami juga memiliki frekuensi kejadian yang tidak pasti, sehingga sulit untuk dapat diprediksi.

Bencana tsunami dapat disebabkan oleh beberapa faktor, di antaranya adalah akibat gempa bumi, letusan gunung api, longsor, tumbukan/ benturan asteroid, fenomena meteorologis, dan aktivitas manusia seperti ledakan bom nuklir (Bryant, 2014; BMKG, 2019; Mutaqin drr., 2019a). Suatu wilayah akan lebih rentan terhadap bencana tsunami apabila mempunyai frekuensi kegempaan yang tinggi maupun jumlah gunung api bawah laut yang banyak. Berdasarkan kriteria tersebut, Indonesia yang merupakan negara kepulauan terbesar di dunia dengan garis pantai terpanjang di dunia mencapai lebih dari 99.000 km (Forbes, 2014; Mutaqin, 2017), termasuk kategori rentan terhadap bencana tsunami. Indonesia secara geologi berada di pertemuan tiga lempeng utama aktif di dunia, yaitu Lempeng Eurasia, Lempeng Indo-Australia, dan Lempeng Pasifik. Hal ini menyebabkan aktivitas seismik di Indonesia sangat intensif. Indonesia juga dilalui banyak jalur gunung api aktif, baik yang ada di daratan maupun bawah permukaan laut. Kondisi geologi dan geomorfologi yang demikian menyebabkan beberapa wilayah di Indonesia dalam kurun waktu 416-2018 pernah terdampak setidaknya 246 kejadian tsunami (BMKG, 2019) (Gambar $1)$.

Salah satu kejadian tsunami yang menimbulkan kerugian besar adalah Tsunami Samudra Hindia (Indian Ocean Tsunami/IOT) pada tahun 2004 (McAdoo drr., 2006; Paris drr., 2009; Wong, 2009). Tsunami yang berdampak besar di Provinsi Aceh tersebut disebabkan oleh gempa bumi mega thrust berskala 9,1 Mw yang terjadi pada episentrum 3,3 $\square$ LU dan 95,8 $\square$ BT(BMKG, 2019; NGDC/WDS, 2019). Kekuatan gempa bumi yang terjadi menciptakan gelombang besar bergerak jauh ke arah daratan. Tsunami ini terdiri atas tiga gelombang utama dengan arah kedatangan berbeda dan ketinggian tsunaminya antara kurang dari 5 meter (gelombang pertama) dan mencapai 30 meter (gelombang kedua) (Paris drr., 2009). Dampak dari gelombang tsunami ini meliputi puluhan negara dan menjadi salah satu catatan buruk Indonesia dalam penanggulangan bencana namun menjadi titik balik dalam manajemen pengurangan risiko bencana di Indonesia (Faturahman, 2018).

Penanggulangan bencana di Indonesia sebelum tsunami 2004 cenderung bersifat responsif terhadap kejadian bencana, pasca dikeluarkannya Undang-Undang Nomor 24 tahun 2007 tentang Penanggulangan Bencana maka kerangka penanggulangan berubah menjadi bersifat preventif. Salah satu upaya pengurangan risiko yang bersifat preventif adalah pengenalan pola kejadian bencana untuk dapat meminimalisasi risiko yang mungkin ditimbulkan dari bencana tersebut. Namun, hal ini menjadi tantangan tersendiri, mengingat pola kejadian bencana tsunami cenderung sulit untuk dapat dikenali. Pemahaman terhadap pola faktor penyebab 


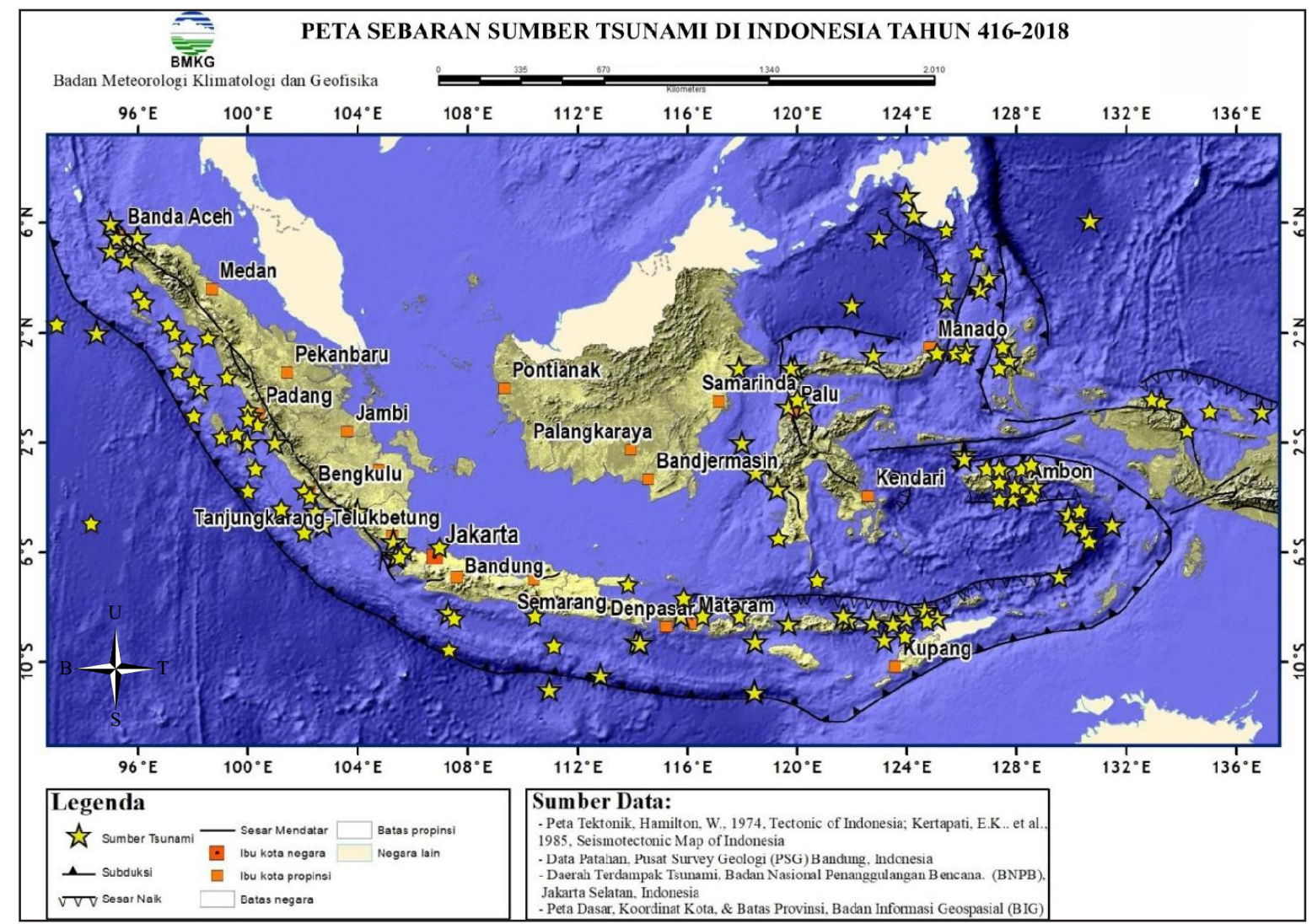

Gambar 1. Peta sebaran sumber tsunami di Indonesia tahun 416-2018 (Sumber: BMKG, 2019 yang dimodifikasi).

tsunami merupakan salah satu pendekatan yang dapat dilakukan untuk mengetahui pola kejadian bencana tsunami. Namun demikian, kajian tersebut masih jarang dilakukan oleh para peneliti di bidang kebencanaan. Kajian terhadap pola bencana tsunami merupakan hal yang penting untuk dilakukan. Kajian terkait kejadian-kejadian bencana di masa lampau dapat menjadi sebuah pelajaran tersendiri bagi perbaikan, peningkatan, atau perubahan bentuk mitigasi bencana yang lebih efektif (Cheema drr., 2016; Hoffmann dan Muttarak, 2017; Mutaqin drr., 2019a; Mutaqin drr., 2019b; Mutaqin dan Lavigne, 2019). Artikel ini menyajikan ulasan dan tinjauan terkait pola spasial kejadian tsunami dan perkembangan manajemen bencana di Indonesia, khususnya tsunami tahun 2004 hingga tahun 2018. Peridode waktu tersebut dipilih sebab tsunami Samudra Hindia tahun 2004 menjadi bencana tsunami dengan dampak terbesar pada abad ke-21 bagi Indonesia. Selain itu, periode waktu tersebut dipilih agar dapat memberikan tinjauan upaya pengurangan risiko yang telah dilakukan pemerintah Indonesia pada kejadian bencana serupa pasca tsunami Samudra Hindia tahun 2004. Tinjauan ini diharapkan dapat meningkatkan pengetahuan dan kesadaran masyarakat tentang bahaya dan risiko tsunami di Indonesia.

\section{METODE PENELITIAN}

Telaah dilakukan terhadap data tsunami yang dikompilasi dari berbagai sumber data. Sumber data yang digunakan antara lain berasal dari: (1) katalog tsunami National Geophysical Data Center/World Data Service (NGDC/WDS) yang dapat diakses pada tautan https://www. ngdc.noaa.gov/hazard/tsu.shtml (NGDC/WDS, 2019), (2) katalog tsunami Badan Meteorologi Klimatologi dan Geofisika (BMKG) pada tautan https://cdn.bmkg.go.id/Web/Katalog-TsunamiIndonesia-pertahun-416-2018.pdf (BMKG, 2019), dan (3) Data Informasi Bencana Indo- 
nesia dari Badan Nasional Penanggulangan Bencana (BNPB) (BNPB, 2011). Tinjauan ini juga dilakukan dengan menggunakan berbagai literatur, seperti artikel pada jurnalilmiah yang membahas kejadian tsunami di Indonesia, buku, Undang-Undang, dan pedoman teknis. Analisis deskriptif dilakukan terhadap distribusi spasial tsunami, factor pemicu tsunami, dampak tsunami, dan kejadian tsunami berdasarkan data penelitian sebelumnya yang dikombinasikan dengan tiga data yang sudah diuraikan sebelumnya. Sistematika telaah secara ringkas disajikan pada Gambar 2.

\section{HASIL DAN PEMBAHASAN}

Tsunami adalah salah satu bencana yang sulit untuk dapat dipahami pola kejadiannya. Berdasarkan 1.340 kejadian tsunami yang te rcatat dari abad ke-4 SM, 1.066 tsunami (79,6\%) disebabkan karena gempa bumi dan 139 tsunami disebabkan karena aktifitas gunung api (NGDC/ WDS, 2019; Mutaqin drr., 2019a). Tsunami pada dasarnya tidak hanya disebabkan oleh satu faktor tunggal, hal ini juga terlihat dari pola kejadian tsunami di Indonesia setelah tsunami Samudra Hindia tahun 2004. Berdasarkan data rekaman bencana tsunami dalam NGDC/WDS (2019) dan BMKG (2019), maka dapat diketahui bahwa pasca Tsunami Samudra Hindia 2004 terdapat 22 total kejadian tsunami di Indonesia selama 2005-2018 dengan berbagai faktor pemicu. Sebanyak tujuh kejadian diantaranya menimbulkan dampak yang signifikan dan disajikan pada Tabel 1.

Berdasarkan Tabel 1 dan Gambar 3 dapat diketahui adanya pola bahwa tsunami besar tersebut mayoritas terjadi pada wilayah barat Pulau Sumatra dan wilayah selatan Pulau Jawa. Selain tsunami utama, terdapat juga tsunamitsunami berskala kecil dengan jumlah kejadian dan frekuensi yang lebih sering dibanding tsunami berskala besar, yaitu terjadi sebanyak 15 kejadian. Tsunami dengan skala kecil tersebut banyak terjadi di wilayah barat Pulau Sumatra terutama di wilayah kepulauan di Pulau Sumatra (Pulau Mentawai dan Pulau Nias).

Pasca tsunami 2004, tsunami setiap tahun terjadi di Indonesia, kecuali pada 2013, 2015, dan 2017. Pola kejadian tsunami di Indonesia pasca tsunami 2004 menunjukkan bahwa frekuensi kejadian tsunami berkekuatan besar lebih sedikit dibanding dengan tsunami berkekuatan kecil (Gambar 4). Berdasarkan Tabel 1 dapat diketahui bahwa tsunami besar terjadi selama 2 tahun berturut-turut (2005 dan 2006) pasca tsunami 2004. Tsunami besar pada tahun berikutnya berselang 5 tahun (2011) dan terjadi lagi 7 tahun berikutnya (2018). Sementara itu,

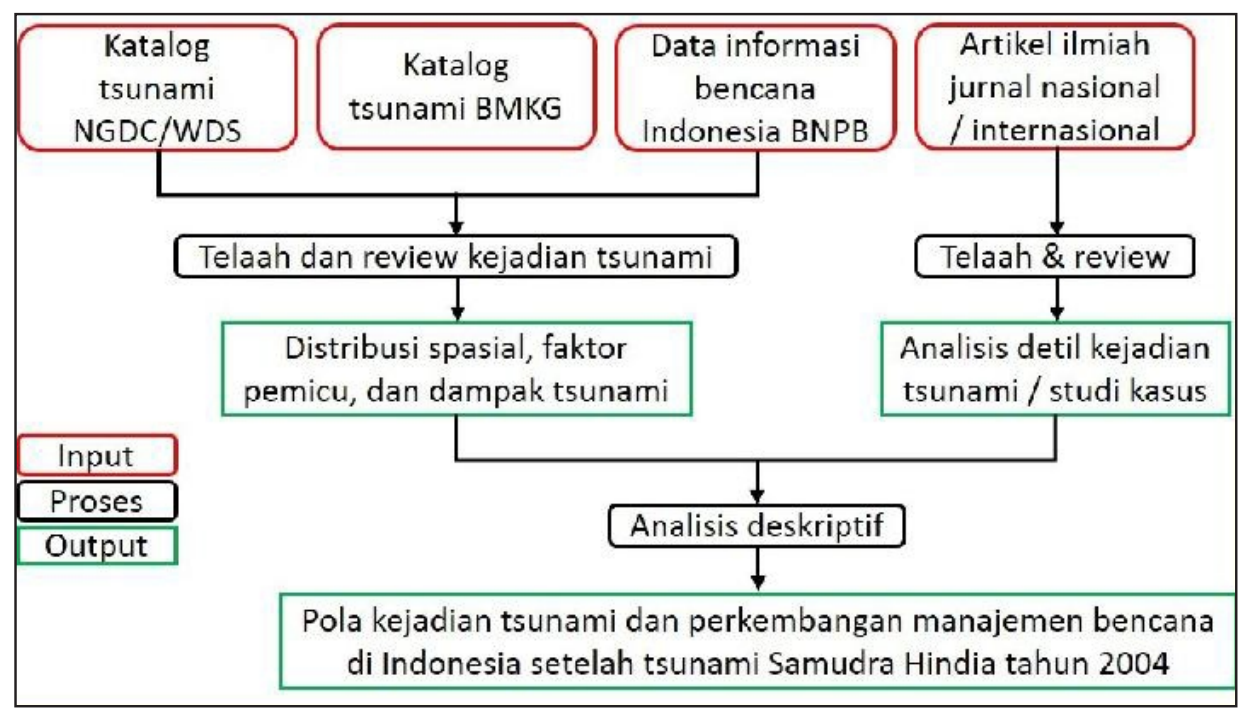

Gambar 2. Sistematika telaah pola kejadian tsunami dan perkembangan manajemen bencana di Indonesia. 
Pola Kejadian Tsunami dan Perkembangan Manajemen Bencana di Indonesia setelah Tsunami Samudra Hindia Tahun 2004: Sebuah Tinjauan

Tabel 1. Data Kejadian Tsunami Berkekuatan Besar di Indonesia

(Sumber: BNPB, 2011; BMKG, 2019; NGDC/WDS, 2019; Takabatake drr., 2019; Mutaqin drr., 2019a)

\begin{tabular}{|c|c|c|c|c|c|c|c|}
\hline No. & Tanggal & $\begin{array}{c}\text { Lokasi } \\
\text { Terdampak }\end{array}$ & Penyebab & Sumber & $\begin{array}{c}\text { Ketinggian Air } \\
\text { Maks. }\end{array}$ & Korban Manusia & $\begin{array}{c}\text { Kerusakan } \\
\text { Infrastruktur }\end{array}$ \\
\hline 1 & $\begin{array}{l}28 \text { Maret } \\
2005\end{array}$ & $\begin{array}{c}\text { Pulau Nias, } \\
\text { Sumatera } \\
\text { Utara } \\
\end{array}$ & $\begin{array}{l}\text { Gempa } \\
\text { bumi }\end{array}$ & $\begin{array}{c}\text { Samudra } \\
\text { Hindia }\end{array}$ & $4,2 \mathrm{~m}$ & 10 orang meninggal & $\begin{array}{l}\text { Beberapa } \\
\text { rumah } \\
\text { hancur } \\
\end{array}$ \\
\hline 2 & $\begin{array}{l}\text { 14 Maret } \\
2006\end{array}$ & $\begin{array}{l}\text { Pulau Buru, } \\
\text { Maluku }\end{array}$ & $\begin{array}{c}\text { Gempa } \\
\text { bumi }\end{array}$ & $\begin{array}{l}\text { Laut } \\
\text { Seram }\end{array}$ & $3,5 \mathrm{~m}$ & $\begin{array}{l}4 \text { orang meninggal } \\
663 \text { orang mengungsi }\end{array}$ & $\begin{array}{l}277 \text { rumah } \\
\text { hancur }\end{array}$ \\
\hline 5 & $\begin{array}{l}11 \text { Maret } \\
2011\end{array}$ & $\begin{array}{l}\text { Jayapura, } \\
\text { Papua }\end{array}$ & $\begin{array}{l}\text { Gempa } \\
\text { bumi }\end{array}$ & $\begin{array}{l}\text { Samudra } \\
\text { Pasifik }\end{array}$ & $3 \mathrm{~m}$ & $\begin{array}{l}1 \text { orang meninggal } \\
67 \text { orang terdampak dan } \\
\text { mengungsi }\end{array}$ & $\begin{array}{c}20 \\
\text { bangunan } \\
\text { hancur }\end{array}$ \\
\hline 6 & $\begin{array}{c}28 \\
\text { September } \\
2018\end{array}$ & $\begin{array}{l}\text { Palu dan } \\
\text { Donggala, } \\
\text { Sulawesi } \\
\text { Tengah }\end{array}$ & $\begin{array}{l}\text { Gempa } \\
\text { bumi dan } \\
\text { longsor }\end{array}$ & $\begin{array}{l}\text { Teluk } \\
\text { Palu }\end{array}$ & $10,67 \mathrm{~m}$ & $\begin{array}{l}3.324 \text { orang meninggal } \\
\text { dan hilang } \\
4.456 \text { orang terluka } \\
5.114 \text { orang terdampak } \\
\text { danmengungsi }\end{array}$ & $\begin{array}{c}101.399 \\
\text { bangunan } \\
\text { hancur }\end{array}$ \\
\hline
\end{tabular}

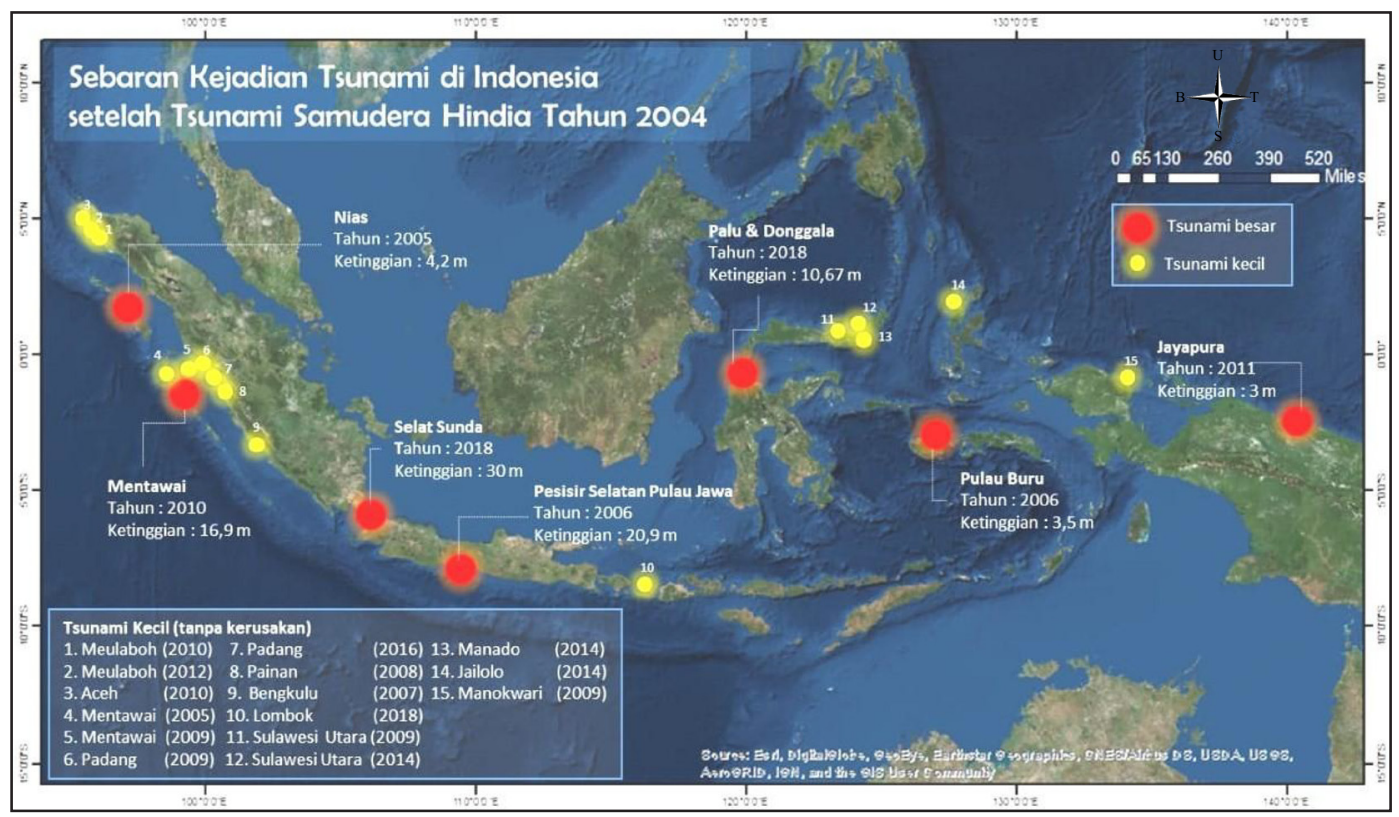

Gambar 3. Distribusi kejadian tsunami di Indonesia setelah IOT 2004

(Sumber: BNPB, 2011; BMKG, 2018; NGDC/WDS, 2019; Takabatake drr., 2019; Mutaqin drr., 2019a). 


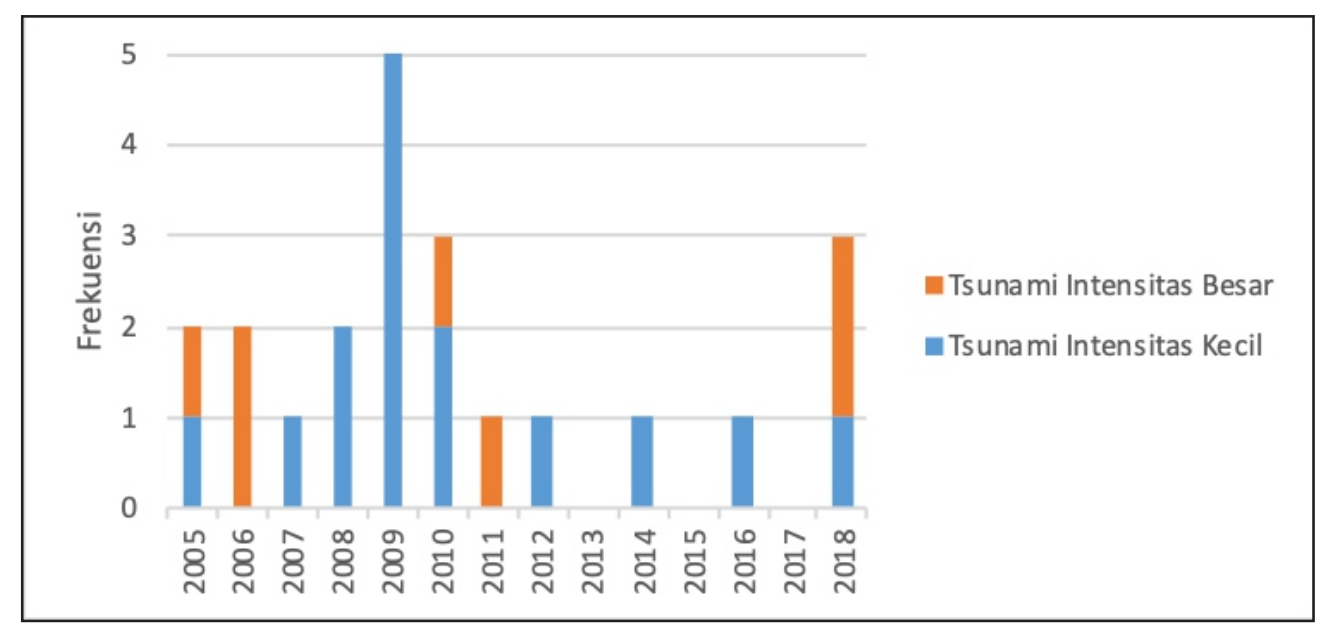

Gambar 4. Frekuensi kejadian tsunami berintensitas besar dan tsunami berintensitas kecil di Indonesia tahun 2005-2018.

kejadian tsunami kecil memiliki frekuensi yang lebih sering, di mana hampir setiap tahunnya terjadi tsunami kecil. Jumlah kejadian tsunami, baik besar maupun kecil, menunjukkan tren yang fluktuatif dengan jumlah kejadian tsunami terbanyak ada pada tahun 2009. Kejadian tsunami di Indonesia pasca tsunami 2004 tidak menunjukkan pola pengulangan yang konsisten, menunjukkan pola sebaran spasial yang jelas yaitu mengelompok pada wilayah barat Pulau Sumatra, selatan Pulau Jawa, dan wilayah kepulauan Maluku dan sebagian Sulawesi.

Tsunami intensitas besar kembali terjadi di Indonesia sebanyak 3 kali, yaitu di Pulau Nias, Pulau Buru, dan selatan Pulau Jawa hanya dalam waktu 2 tahun pasca tsunami 2004 (Lavigne drr., 2007; Pariatmono, 2012; Satake drr., 2013; Paris drr., 2014). Di antara ketiga tsunami tersebut, dampak terparah akibat tsunami terdapat di selatan Pulau Jawa. Ketinggian maksimal tsunami di selatan Pulau Jawa juga lebih besar daripada 2 tsunami lain di Pulau Nias dan Pulau Buru, meskipun magnitudo gempa bumi di selatan Pulau Jawa lebih kecil dari gempa bumi di Nias. Tsunami ini bahkan tercatat sebagai earthquake-triggered tsunami paling mematikan sepanjang masa di pulau tersebut (Lavigne drr., 2007). Penyebab dari banyaknya korban pesisir selatan Jawa selain karena besarnya intensitas tsunami ialah karena tidak tersedianya sistem peringatan dini untuk bencana tsunami.
Pada 2010-2011, tsunami intensitas besar terjadi sebanyak 2 kali yaitu di Kepulauan Mentawai dan Jayapura. Tsunami Mentawai dipicu oleh gempa bumi besar berkekuatan 7,8 Mw (Pariatmono, 2012; Satake drr., 2013). Wilayah ini mengalami seismic gap karena gempa bumi besar terakhir kali terjadi pada 1833 (Satake drr., 2013). Pengalaman historis kebencanaan yang terlupakan terbukti menimbulkan dampak yang sangat besar (Satake drr., 2013; Mutaqin drr., 2019a). Sementara itu, peristiwa tsunami di Jayapura pada 2011 merupakan kejadian farfield tsunami pertama yang terjadi di Indonesia selama abad 21. Kejadian tsunami di Jayapura dipengaruhi oleh kejadian tsunami di Tohoku, dimana kedua tsunami tersebut dipicu oleh satu gempa yang sama dengan selisih waktu kejadian 6 jam (Diposaptono drr., 2013). Fakta ini menunjukkan bahwa kejadian tsunami dapat dipicu oleh pusat gempa bumi yang jauh dari lokasi terjadinya tsunami, bahkan hingga lintas negara. Dampak yang ditimbulkan juga tidak sedikit. Hal ini memberi pelajaran bagi Indonesia bahwa dampak far-field tsunami tidak boleh diremehkan. Pada kejadian tsunami di Jayapura, BMKG telah memberikan peringatan tsunami melalui radio yang kemudian direspon dengan evakuasi masyarakat sehingga korban meninggal dunia hanya 1 orang. Namun, 20 bangunan tercatat mengalami kerusakan akibat peristiwa tersebut (Diposaptono drr., 2013; BMKG, 2019). 
Kejadian tsunami intensitas tinggi sempat mengalami jeda yang cukup lama (7 tahun) pasca tsunami Jayapura 2011. Tahun 2018 tercatat terdapat 2 kejadian tsunami yang dipicu oleh faktor non seismik yaitu tsunami di Palu dan Donggala (Arikawa drr., 2018; Muhari drr., 2018; Syamsidik drr., 2019) serta tsunami di Selat Sunda (Takabatake drr., 2019). Faktor pemicu tsunami Palu dan Donggala tahun 2018 berupa gempa bumi dan longsor, sementara itu pada tsunami Selat Sunda tahun 2018 faktor pemicunya berupa letusan gunungapi Anak Krakatau dan longsor sebagian badan gunungapi Anak Krakatau. Mekanisme tsunami di Palu dan Donggala itu sendiri tidak lazim karena berasal dari pergerakan strike-slip fault dan berpusat di daratan. Hal ini pun dibuat semakin kompleks karena beberapa penelitian menunjukkan bahwa mekanisme tsunaminya diduga lebih dipengaruhi oleh longsor bawahlaut, aerial landslide, hingga subsidensi karena periode gelombangnya pendek (Arikawa drr., 2018; Muhari drr., 2018; Syamsidik drr., 2019). Jumlah korban jiwa akibat tsunami tersebut tercatat sebanyak lebih dari 3.000 jiwa sehingga tsunami ini dikategorikan sebagai bencana alam dengan korban jiwa terbesar setelah tsunami Samudra Hindia 2004 selama abad 21 di Indonesia. Faktor utama yang menyebabkan besarnya korban jiwa tersebut ialah singkatnya masa evakuasi (kurang dari 4 menit) dan kegagalan diseminasi peringatan dini kemasyarakat.

Sementara itu, mekanisme tsunami di Selat Sunda pada 2018 juga sangat jarang terjadi. NGDC/ WDS (2019) mencatat tsunami di Indonesia dengan mekanisme serupa terjadi terakhir kali pada 1928 di Flores. Menurut klasifikasi Paris drr. (2014) dan Mutaqin drr. (2019a), mekanisme sumber tsunami tersebut berasal dari subaerial failure Gunung api Anak Krakatau. Karena belum adanya sistem peringatan dini yang mampu menangkap potensi tsunami vulkanik, masyarakat tidak menyadari gejala tsunami sehingga jumlah korban jiwa cukup besar. Kejadian tsunami serupa di Selat Sunda pernah terjadi pada tahun 1883, erupsi besar Gunungapi Anak
Krakatau dengan Volcanic Explosive Index (VEI) 6 telah menyebabkan tsunami setinggi 30 meter di sepanjang pesisir Selat Sunda sebagai akibat dari masuknya material letusan ke dalam laut (Verbeek, 1885; Maeno dan Imamura, 2011; Mutaqin drr., 2019a). Meskipun sama-sama tergolong sebagai tsunami vulkanik, mekanisme sumber tsunami Krakatau 1883 berasal dari aliran piroklastik (Maeno dan Imamura, 2011; Paris drr., 2014; Mutaqin drr., 2019a). Hal ini menunjukkan pentingnya pengamatan potensi tsunami vulkanik yang mekanisme sumbernya relatif kompleks agar risiko di masa depan dapat dikurangi (Mutaqin drr., 2019a; Mutaqin drr., 2019b).

Manajemen bencana di Indonesia beberapa kali mengalami perubahan sistem. Hal ini ditunjukkan pada Gambar 5 mengenai perubahan institusional manajemen bencana sejak 1945 hingga 2008. Penanganan bencana di Indonesia pada awal kemerdekaan hanya fokus pada korban perang. Selanjutnya, pemerintah mulai fokus pula pada bencana alam dan non alam melalui pembentukan institusi ad hoc yang beberapa kali mengalami perubahan nama hingga terbentuknya badan koordinasi dan baru pada 2008 menjadi institusi tersendiri yang berfungsi mengkoordinasikan kegiatan penanggulangan bencana secara menyeluruh serta sudah memiliki anggaran tersendiri (James, 2008; Lassa, 2013; Intarti drr., 2013; Das dan Luthfi, 2017).

Pengurangan risiko bencana, termasuk tsunami, belum menjadi prioritas utama pemerintah dalam aspek manajemen bencana sebelum terjadinya tsunami Samudra Hindia 2004. Faktanya, beberapa tsunami besar sebenarnya sudah terjadi beberapa kali di Indonesia sebelum tsunami 2004 serta turut menimbulkan banyak korban jiwa maupun kerugian ekonomi. BMKG (2018) mencatat setidaknya ada 6 peristiwa tsunami di Indonesia yang menyebabkan 100 atau lebih orang meninggal selama 1945-2003. Bencana tsunami Flores pada 1992 bahkan menjadi bencana tsunami yang paling destruktif selama abad 20, di mana peristiwa tersebut 


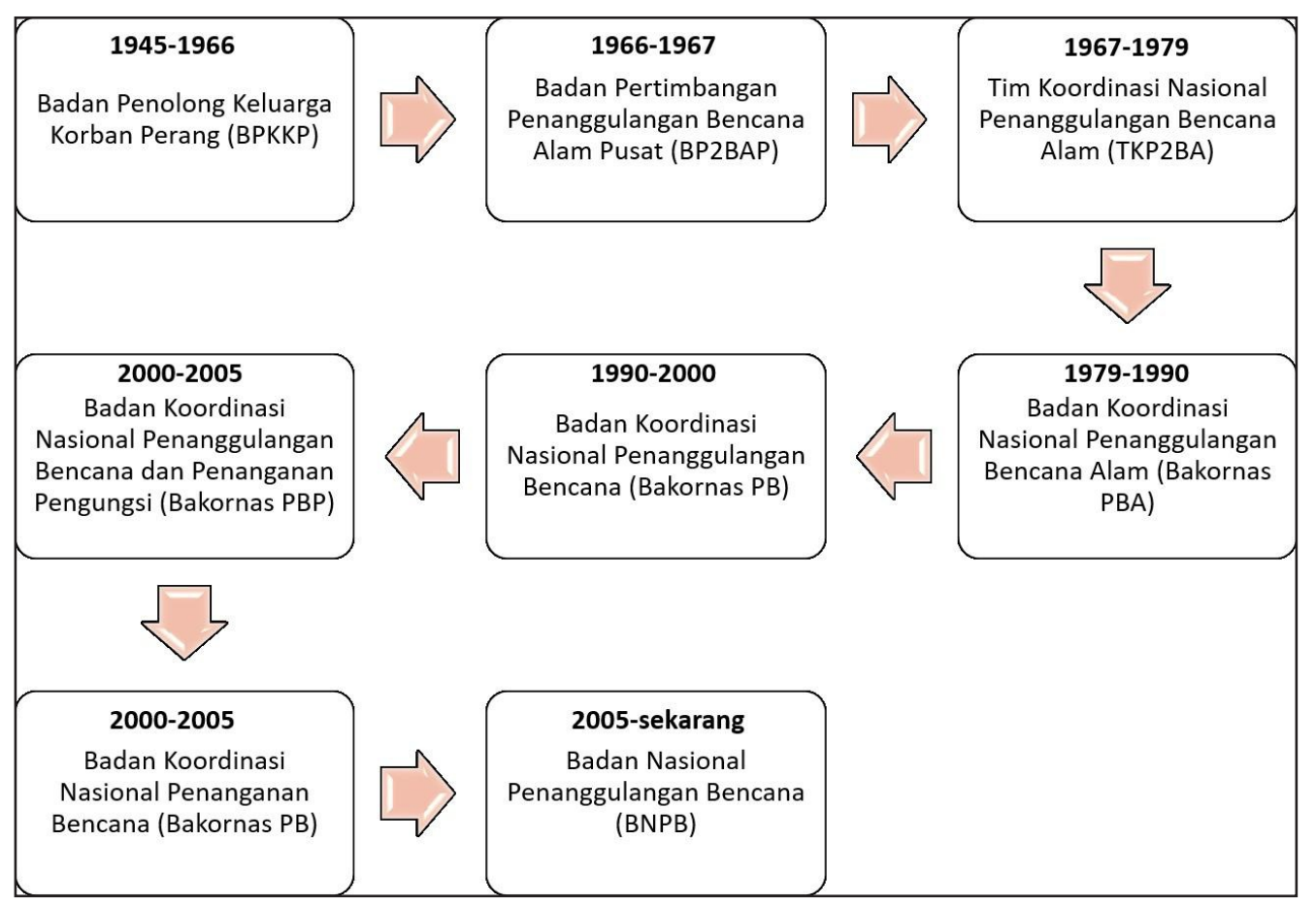

Gambar 5. Sejarah perubahan institusi manajemen bencana di Indonesia (BNPB, 2020).

menyebabkan sekitar 2.500 jiwa meninggal. Meskipun bencana tersebut ditetapkan sebagai bencana nasional (seperti kasus tsunami 2004), sistem manajemen bencana di Indonesia tidak mengalami perubahan secara berarti (Lassa, 2013). Paradigma penanganan bencana terdahulu masih cenderung reaktif karena hanya berfokus pada respon kedaruratan dan hanya ada sedikit mekanisme khusus yang dilakukan untuk upaya preventif (James, 2008; Das dan Luthfi, 2017).

Peristiwa tsunami Samudra Hindia 2004 memberikan jendela kesempatan (windows of opportunity) bagi perkembangan pengurangan risiko bencana secara keseluruhan, baik pada skala nasional di Indonesia maupun internasional (Djalante drr., 2012). Pasca peristiwa tersebut, paradigma manajemen bencana yang proaktif mulai menjadi perhatian utama, terutama sejak pembentukan Badan Nasional Penanggulangan Bencana (BNPB) pada 2008. Pemerintah juga memformulasikan regulasi kunci terkait manajemen bencana (misalnya Undang-Undang Nomor 24 Tahun 2007 tentang Penanggulangan Bencana), serta penetapan Rencana Nasional
Penanggulangan Bencana dan Rencana Aksi Nasional Penanggulangan Risiko Bencana. Sistem manajemen bencana yang pada awalnya merupakan tanggungjawab pemerintah pusat sepenuhnya menjadi terdesentralisasi melalui pelibatan pemerintah lokal. Selain itu, Indonesia turut meratifikasi Hyogo Framework for Action (HFA) pada 2005 di mana indikator kuncinya menjadi landasan bagi kebijakan pengurangan risiko bencana di Indonesia.

Salah satu langkah penting lain yang dilakukan dalam pengurangan risiko tsunami ialah instalasi sistem peringatan dini (Indonesia Tsunami Early Warning System/InaTEWS) pada 2005 dan selesai pada 2008 (Mardiatno dan Mutaqin, 2011). InaTEWS memiliki 3 konsep dasar di antaranya komponen operasional, mitigasi dan respon kondisi darurat, serta pembangunan kapasitas (BMKG, 2010). Peringatan dini tsunami di Indonesia tidak menjadi tugas utama BNPB, melainkan Badan Meteorologi, Klimatologi, dan Geofisika (BMKG). Meskipun demikian, penerapan InaTEWS melibatkan belasan institusi nasional lainnya serta didukung oleh beberapa negara donor, organisasi internasional dan 
non-governmental organization (NGO). Desain InaTEWS terdiri atas sistem pemantauan darat (seperti stasiun seismik dan global positioning system) dan laut (seperti buoy dan tide gauges) serta sistem komunikasi berbasis satelit. Peringatan potensi tsunami akan muncul hanya dalam waktu 5 menit pasca gempa bumi terjadi dengan beberapa kriteria tertentu: (1) magnitudo gempa bumi $\geq 7 \mathrm{Mw}$, (2) sumber gempa bumi berada di bawah laut dengan kedalaman $\leq 100$ kilometer, (3) terjadi deformasi vertikal berupa dip-slip fault, dan (4) jarak pusat gempa bumi dari pantai memungkinkan terbentuknya tsunami (BMKG, 2012). Pemerintah meluncurkan program pembangunan tempat evakuasi sementara, konservasi hutan pantai dan gumuk, perencanaan tata ruang, dan pemetaan bahaya tsunami untuk mendukung kinerja sistem peringatan dini dalam hal pengurangan risiko.

Dari beberapa kejadian tsunami di Indonesia pasca-Tsunami Samudra Hindia 2004, ada beberapa pelajaran sekaligus tantangan baru dalam manajemen bencana tsunami. Selama 2005-2008, terdapat empat kejadian tsunami kecil dan tiga kejadian tsunami utama di Indonesia seperti tsunami Nias 2005, tsunami Buru 2006, dan tsunami Jawa 2006. Periode ini dapat dikatakan sebagai transisi perubahan paradigma dalam manajemen bencana dengan Bakornas Penanganan Bencana sebagai institusi yang bertanggungjawab dalam mengkoordinasikan pelaksanaan penanganan bencana. Dengan jumlah total tsunami sebanyak 7 kejadian dalam kurun waktu 3 tahun saja, hal ini menunjukkan pentingnya penyelesaian instalasi sistem peringatan dini sesegera mungkin.

Pasca reformasi sistem manajemen bencana di Indonesia (termasuk pembentukan BNPB dan penyelesaian konstruksi InaTEWS), tsunami skala besar terjadi di Kepulauan Mentawai, Sumatera Barat pada 2010. Tsunami ini seolah menjadi percobaan pertama bagi Indonesia untuk menilai sejauh mana perkembangan pengurangan risiko tsunami. Meskipun peringatan tsunami telah dikeluarkan 5 menit pasca gempa bumi terjadi, dampak kejadian tsunami tersebut masih sangat besar (Tabel 1). Hasil penelitian Pariatmono (2012) menunjukkan bahwa ada beberapa faktor yang menyebabkan besarnya jumlah korban jiwa di Mentawai akibat tsunami 2010 meskipun InaTEWS telah beroperasi. Pertama, kurangnya ketersediaan fasilitas umum, termasuk listrik dan komunikasi, serta aksesibilitas transportasi yang buruk. Kedua, tidak adanya kearifan lokal terkait pengurangan risiko tsunami. Ketiga, sebagian besar penduduk tidak menerima informasi secara resmi dari otoritas meskipun BMKG telah memberi peringatan karena keterbatasan fasilitas komunikasi. Karena hal tersebut, BMKG melakukan perubahan skema peringatan dengan harapan dampak kejadian tsunami selanjutnya dapat dikurangi (BMKG, 2012).

Sistem peringatan dini tsunami juga mengalami permasalahan pada saat kejadian tsunami di Jayapura 2011 (Diposaptono drr., 2013). Masyarakat pada saat itu sebenarnya telah berhasil mengevakuasi diri ke area perbukitan setelah menerima peringatan tsunami pertama. Namun demikian, peringatan tersebut diberhentikan ketika tide gauges masih mengamati adanya tsunami. Hal ini mengakibatkan masyarakat justru menginterpretasi kondisi di wilayah terdampak tsunami telah aman. Situasi tersebut pada akhirnya mengakibatkan korban jiwa, yaitu meninggalnya orang yang kembali ke dataran rendah dikarenakan terbawa gelombang tsunami susulan. Oleh karena itu, sistem pemantauan laut dan pusat peringatan harus diintegrasikan secara baik agar tidak lagi terjadi pembatalan peringatan yang tidak perlu.

Adanya tsunami Palu dan Donggala 2018 serta tsunami Selat Sunda 2018 turut menunjukkan bahwa sistem peringatan dini tsunami masih perlu dibenahi. Kedua tsunami tersebut disebabkan oleh faktor non-seismik sehingga InaTEWS belum dapat mendeteksinya. Pada kasus tsunami Palu dan Donggala, BMKG sebenarnya telah mengeluarkan peringatan dini tsunami meskipun episentrumnya di darat dan dipengaruhi oleh mekanisme sesar geser. Namun, kejadian tsunami tersebut datang lebih 
cepat dari peringatan dini karena waktu tiba tsunami hanya kurang dari 4 menit setelah gempa bumi (UNDRR dan UNESCO-IOC, 2019). Singkatnya waktu kedatangan tsunami diduga disebabkan oleh faktor lokal berupa longsor yang memicu ketidakstabilan kolom air. Pada kasus tsunami Selat Sunda, BMKG bahkan sama sekali tidak dapat mengirimkan informasi peringatan dini karena tidak adanya alat yang mampu mendeteksi tsunami vulkanik meskipun sebelumnya sudah dapat diidentifikasi material gunungapi Anak Krakatau yang masuk ke laut (Mutaqin drr., 2019a; Takabatake drr., 2019). Hal inilah yang menjadi faktor utama besarnya korban jiwa yang ditimbulkan pada kedua kejadian tsunami tersebut. Masyarakat di area terdampak kehilangan golden time untuk menyelamatkan diri dari tsunami. Pelajaran utama yang dapat diambil dari kedua peristiwa tersebut adalah pentingnya sistem peringatan dini tsunami non-seismik karena selama ini InaTEWS hanya dapat mendeteksi potensi tsunami akibat gempa bumi tektonik. Selain itu, kesadaran masyarakat akan potensi tsunami di wilayahnya juga perlu ditingkatkan (Mutaqin drr., 2019a). Masyarakat semestinya tidak menunggu sirine tsunami berbunyi, melainkan langsung melakukan evakuasi mandiri terutama jika terjadi gempa bumi yang magnitudonya besar maupun gempa bumi kecil dengan durasi yang lama.

\section{KESIMPULAN}

Pada periode 2005-2018 tercatat ada 22 kejadian tsunami di Indonesia, dimana 7 kejadian tsunami mempunyai dampak yang signifikan yaitu tsunami di Pulau Nias (2005), Pulau Buru (2006), Pulau Jawa bagian selatan (2006), Kepulauan Mentawai (2010), Jayapura (2011), Palu dan Donggala (2018), dan kepesisiran Selat Sunda (2018). Dampak yang diakibatkan oleh 7 kejadian tsunami tersebut adalah 15 orang meninggal, 4.963 orang meninggal dan hilang, 19.533 orang terluka, 69.056 orang terdampak dan mengungsi, serta 107.581 bangunan hancur. Besarnya kerugian yang disebabkan oleh bencana tsunami Samudra Hindia 2004 dan juga tsunami dalam periode waktu 2005-2018 seharusnya dapat menjadi bahan pembelajaran bagi Indonesia dalam mengembangkan model pengurangan risiko yang lebih baik. Hal ini pada dasarnya telah direspon melalui perubahan paradigma manajemen bencana melalui instrumen perundang-undangan, namun dalam praktiknya penerapan paradigma baru tersebut belum maksimal. Upaya preventif masih belum maksimal dilakukan pemerintah terbukti dengan masih banyaknya korban jiwa yang terdampak tsunami setelah tsunami Samudra Hindia 2004. Peran sistem peringatan dini sebagai wujud dari upaya pencegahan dinilai tidak maksimal karena belum mampu merespon pada jenis-jenis tsunami yang dipicu oleh faktor non seismik seperti tsunami di Palu-Donggala dan Selat Sunda pada tahun 2018 serta terbatasnya infrastruktur diseminasi.

Beberapa kegagalan dalam pengurangan risiko dari bencana tsunami yang terjadi 14 tahun terakhir tidak hanya berasal dari kegagalan sistem peringatan dini, namun juga berasal dari penataan ruang yang masih menempatkan pusat-pusat penduduk di wilayah rawan bencana (Mardiatno dan Mutaqin, 2011). Tsunami Samudra Hindia 2004 dengan korban yang begitu banyak seharusnya dapat menjadi pelajaran bagi pemerintah untuk tidak menempatkan pusatpusat penduduk di wilayah rawan bencana, namun faktanyasaat ini masih banyak wilayah rawan bencana yang dipadati permukiman penduduk. Salah satu dampak fatalnya yang baru saja terjadi adalah tsunami Palu dan Donggala, tsunami yang disertai bencana likuifaksi telah menimbulkan banyak korban jiwa sebab lokasi bencana adalah juga lokasi pusat permukiman. Kejadian tersebut seharusnya dapat menjadi pembelajaran bahwa upaya pengurangan risiko bencana tidak hanya dimaknai secara sempit sebagai kewajiban BNPB saja melainkan juga kewajiban semua sektor, salah satunya sektor tata ruang wilayah. Pola dan struktur ruang di Indonesia kedepan harus disesuaikan dengan potensi tsunami yang ada di suatu wilayah, 
misalnya dengan menempatkan penduduk tidak pada lokasi rawan tsunami dan menerapkan proteksi alami terhadap tsunami (pembuatan greenbelt, konservasi gumuk pasir dan terumbu karang).

Terakhir dan tidak kalah penting, kesadaran masyarakat akan potensi tsunami dan pembentukan tsunami subculture sangat mempengaruhi responnya terhadap tsunami mendatang. Pengurangan risiko tsunami tidak cukup dilakukan dengan improvisasi teknologi, tetapi juga harus melalui upaya peningkatan kapasitas masyarakat karena mereka adalah subjek utama dalam manajemen kebencanaan. Masyarakat seharusnya mampu mengambil pelajaran dari kejadian tsunami masa lampau untuk mengurangi risiko kedepannya. Salah satu contoh suksesnya ialah terselamatkannya ribuan jiwa di Pulau Simeulue akibat Tsunami Samudra Hindia 2004 karena kearifan lokal smong yang telah ada sejak pascatsunami 1907 (McAdoo drr., 2006). Evakuasi mandiri (tanpa menunggu respon peringatan dini) merupakan kunci dari pengurangan jumlah korban jiwa akibat tsunami, yang tentunya didukung dengan penyediaan tempat dan jalur evakuasi yang memadai serta memanfaatkan waktu krisis sebaik-baiknya untuk menyelamatkan diri.

\section{UCAPAN TERIMA KASIH}

Penulis mendedikasikan artikel ini kepada almarhum Prof. Sunarto dan Prof. Hartono. Akhirnya, penulis menyampaikan terima kasih kepada reviewer atas komentar dan masukkan yang membangun untuk perbaikan artikel ini.

\section{DAFTAR PUSTAKA}

Asaoka, A., 1978.Observational Procedure of Settlement Prediction, Soils and Foundation, No.4.

Arikawa, T., Muhari, A., Okumura, Y., Dohi, Y., Afriyanto, B., Sujatmiko, K.A., dan Imamura, F. 2018. Coastal Subsidence Induced Several Tsunamis During the 2018 Sulawesi
Earthquake. Journal of Disaster Research. Vol.13 Sci. Comm., sc20181204, 2018.

$\mathrm{BMKG}, 2010$. InaTEWS Indonesia Tsunami Early Warning System: Concept and Implementation. Jakarta: BMKG.

BMKG, 2012. Pedoman Pelayanan Peringatan Dini Tsunami InaTEWS. Jakarta: BMKG. BMKG, 2018. Katalog Tsunami Indonesia Tahun 416 - 2017. Jakarta: BMKG.

BMKG, 2019. Katalog Tsunami Indonesia Tahun 416 - 2018. Jakarta: BMKG. BNPB, 2011. Peta zonasi ancaman bencana tsunami di Indonesia. Jakarta: BNPB.

BNPB, 2020. Sejarah Berdirinya BNPB. https:// bnpb.go.id/sejarah-bnpb. Diakses pada tanggal 25 September 2020.

Bryant, Edward. 2014. Tsunami: The Underrated Hazard. Cham: Springer International Publishing. https://doi.org/10.1007/978-3319-06133-7.

Cheema A.R, Mehmood A., dan Imran M., 2016. Learning from the Past Analysis of Disaster Management Structures, Policies and Institutions in Pakistan, Disaster Prevention and Management, Vol. 25 (4): 449-463. https:// doi.org/10.1108/DPM-10-2015-0243.

Das, A. dan Luthfi, A. 2017. Disaster Risk Reduction in Post-Decentralisation Indonesia: Institutional Arrangements and Changes. dalam Djalante, R., Garschagen, M., Thomalla, F., dan Shaw, R. (eds). Disaster Risk Reduction in Indonesia: Progress, Challenges, and Issues. Cham: Springer International Publishing. pp. 85-125. https://doi. org/10.1007/978-3-319-54466-3 4.

Diposaptono, S., Muhari, A., Imamura, F., Koshimura, S., dan Yanagisawa, H. 2013. Impacts of the 2011 East Japan Tsunami in the Papua Region, Indonesia: Field Observation Data and Numerical Analyses. Geophysical Journal International. Vol. 194: 1625-1639. https://doi.org/10.1093/gji/ggt175.

Djalante, R., Thomalla, F., Sinapoy, M.S., dan Carnegie, M. 2012. Building Resilience to Natural Hazards in Indonesia: Progress and Challenges in Implementing the Hyogo 
Framework for Action. Natural Hazards. Vol. 62: 779-803. https://doi.org/10.1007/ s11069-012-0106-8.

Faturahman, B.M. 2018. Konseptualisasi Mitigasi Bencana Melalui Perspektif Kebijakan Publik. Jurnal Ilmu Administrasi Publik. Vol. 3 (2): 122-134.

Forbes, V.L. 2014. Indonesia's Delimited Maritime Boundaries. Berlin: Springer-Verlag. https://doi.org/10.1007/978-3-642-54395-1.

Hoffmann, R., dan Muttarak R., 2017, Learn from the Past, Prepare for the Future: Impacts of Education and Experience on Disaster Preparedness in the Philippines and Thailand, World Development, Vol. 96: 32-51. https://doi.org/10.1016/j.worlddev.2017.02.016.

Intarti, Y.R., Fitrinitia, I.S., Widyanto, M.R., dan Simarmata, H.A. 2013. Towards Disaster Management in Indonesia Case Studies: Jakarta and Yogyakarta Provinces. International Journal of Disaster Recovery and Business Continuity. Vol. 4: 11-22.

James, E. 2008. Getting Ahead of the Next Disaster: Recent Preparedness Efforts in Indonesia.

Development in Practice. Vol. 18 (3): 424-429. https://doi.org/10.1080/09614520802030607.

Lassa, J.A. 2013. Disaster Policy Change in Indonesia 1930-2010: From Government to Governance?

International Journal of Mass Emergencies and Disasters. Vol. 31 (2): 130-159.

Lavigne, F., Gomez, C., Giffo, M., Wassmer, P., Hoebreck, C., Mardiatno, D., Prioyono, J., dan Paris, R. 2007. Field Observations of the 17 July 2006 Tsunami in Java. Natural Hazards and Earth System Sciences. Vol. 7: 177-183. https://doi.org/10.5194/ nhess-7-177-2007.

Maeno, F., dan Imamura, F., 2011, Tsunami Generation by a Rapid Entrance of Pyroclastic Flow into The Sea during 1883 Krakatau Eruption, Indonesia, Journal of Geophysical Research, Vol. 116, B09205. https://doi. org/10.1029/2011JB008253.
Mardiatno D. dan Mutaqin B.W. 2011. Spatiotemporal Modelling of Population Distribution for the Tsunami Risk Assessment in Pacitan, Indonesia. The Investigation Report of 2004 Northern Sumatra Earthquake (Additional Volume) - Graduate School of Environmental Studies, Nagoya University: Nagoya, Japan. http://www.seis.nagoya-u. ac.jp/INFO/sumatra/.

McAdoo, B.G., Dengler, L., Prasetya, G., dan Titov, V. 2006. Smong: How an Oral History Saved Thousands on Indonesia's Simeulue Island during the December 2004 and March 2005 Tsunamis. Earthquake Spectra. Vol. 22 (53): S661-S669. https://doi. org/10.1193/1.2204966.

Muhari, A., Imamura, F., Arikawa, T., Hakim, A.R., dan Afriyanto, B. 2018. Solving the Puzzle of the September 28 Palu, Indonesia, Tsunami Mistery: Clues from the Tsunami Waveform and the Initial Field Survey Data. Journal of Disaster Reseach. Vol.13 Sci. Comm., sc20181108, 2018.

Mutaqin B.W. 2017. Shoreline Changes Analysis in Kuwaru Coastal Area, Yogyakarta, Indonesia: An Application of the Digital Shoreline Analysis System (DSAS). International Journal of Sustainable Develop ment and Planning 12(7), pp. $1203-$ 1214. https://doi.org/10.2495/SDP- V12N7-1203-1214.

Mutaqin B.W., Lavigne F., Hadmoko D.S., Malawani M.N. 2019a, Volcanic EruptionInduced Tsunami in Indonesia: A Review, IOP Conf. Ser.: Earth Environ. Sci. 256 012023. https://doi.org/10.1088/1755-1315 /256/1/012023.

Mutaqin B.W., Lavigne F., Sudrajat Y., Handayani L., Lahitte P., Virmoux C., Hiden, Hadmoko D.S., Komorowski J.C., Hananto N., Wassmer P., Hartono, Boillot-Airaksinen K. 2019b. Landscape evolution on the eastern part of Lombok (Indonesia) related to the 1257 CE eruption of the Samalas Volcano, Geomorphology 327, pp. 338-350. https:// doi.org/10.1016/j.geomorph.2018.11.010. 
Mutaqin B.W. and Lavigne F. 2019. Oldest Description of a Caldera-forming Eruption in Southeast Asia Unveiled in Forgotten Written Sources, GeoJournal. https://doi. org/10.1007/s10708-019- 10083-5.

NGDC/WDS. 2019. NCEI/WDS Global Historical Tsunami Database. Diakses pada 12 November 2019 melalui https://www.ngdc. noaa.gov/hazard/tsu_db.shtml.

Pariatmono. 2012. The Influence of Mentawai Tsunami to Public Policy on Tsunami Warning in Indonesia.

Journal of Disaster Research. Vol. 7 (1): 102106.

Paris, R., Switzer, A.D., Belousova, M., Belousov, A., Ontowirjo, B., Whelley, P.L., dan Ulvrova, M. 2014. Volcanic Tsunami: A Review of Source Mechanisms, Past Events and Hazards in Southeast Asia (Indonesia, Phillipines, Papua New Guinea). Natural Hazards. Vol. 70: 447-470. https://doi. org/10.1007/s11069-013-0822-8.

Paris, R., Wassmer, P., Sartohadi, J., Lavigne, F., Barthomeuf, B., Desgages, E., Grancher, D., Baumert, P., Vautier, F., Brunstein, D., dan Gomez, C. 2009. Tsunamis as Geomorphic Crises: Lessons from the December 26, 2004 Tsunami in Lhoknga, West Banda Aceh (Sumatra, Indonesia). Geomorphology. Vol. 104: 59-72. https://doi.org/10.1016/j. geomorph.2008.05.040.

Satake, K., Nishimura, Y., Putra, P.S., Gusman, A.R., Sunendar, H., Fujii, Y., Tanioka, Y., Latief, H., dan Yulianto, E. 2013. Tsunami Source of the 2010 Mentawai, Indonesia
Earthquake Inferred from Tsunami Field Survey and Waveform Modeling. Pure and Applied Geophysics. Vol. 170: 1567- 1582. https://doi.org/10.1007/s00024-012-0536-y. Syamsidik, Benazir, Umar, M., Margaglio, G., dan Fitrayansyah, A. 2019. Post-Tsunami Survey of the 28 September 2018 Tsunami near Palu Bay in Central Sulawesi, Indonesia: Impacts and Challenges to Coastal Communities. International Journal of Disaster Risk Reduction. Vol. 38: 101229. https://doi. org/10.1016/j.ijdrr.2019.101229.

Takabatake, T., Shibayama, T., Esteban, M., Achiari, H., Nurisman, N., Gelfi, M., Tarigan, T.A., Kencana, E.R., Fauzi, M.A.R., Panalaran, S., Harnantyari, A.S., dan Kyaw, T.O. 2019. Field Survey and Evacuation Behaviour during the 2018 Sunda Strait Tsunami. Coastal Engineering Journal. Vol. 61 (4): 432-443. https://doi.org/10.1080 /21664250.2019.1647963.

Undang-Undang Republik Indonesia Nomor 24 Tahun 2007 tentang Penanggulangan Bencana.

UNDRR dan UNESCO-IOC. 2019. Limitations and Challenges of Early Warning Systems: A Case Study from the 2018 Palu-Donggala Tsunami. Jakarta: UNDRR.

Verbeek, R.D.M., 1885, Krakatau, Batavia: Government Press.

Wong, P.P. 2009. Impacts and Recovery from a Large Tsunami: Coasts of Aceh. Polish Journal of Environmental Studies. Vol. 18 (1): 5-16. 